http://dx.doi.org/10.18778/8088-187-7.24

Wojciech Witkowski

\title{
Kwestia tzw. juristitium oraz działań Rady Stanu Królestwa Polskiego w okresie powstania listopadowego
}

1 Uwagi niniejsze dotyczyć będą tej części Rady Stanu, którą powszechnie w Królestwie Polskim utożsamiano z Ogólnym Zgromadzeniem, a z rzeczowego punktu widzenia jej kompetencji administracyjnych i sądowych. Po 1815 r. Rada Stanu przestała już pełnić funkcje sądu kasacyjnego, pozostało przy niej natomiast ostateczne orzekanie w ramach sądownictwa kompetencyjnego (tzw. wówczas jurysdykcyjnego) i administracyjnego oraz wydawanie decyzji o oddaniu pod sąd urzędników publicznych, mianowanych przez króla, za przestępstwa popełnione w związku z urzędowaniem ${ }^{1}$. Drugim organem w kręgu uwag będzie Komisja Rządowa Sprawiedliwości z ministrem prezydującym na czele. Miejscem z kolei zasadniczej dyskusji w przedmiotowej sprawie wznowienia funkcjonowania Rady Stanu pozostaje forum Sejmu powstaniowego.

W latach osiemdziesiątych ubiegłego wieku Radzie Stanu jako najwyższej instancji sądownictwa administracyjnego i organowi w rozstrzyganiu sporów kompetencyjnych oraz resortowi sprawiedliwości w Królestwie Polskim poświęciłem dwie monografie ${ }^{2}$. W nich też szczegółowo wskazałem na skład, kompetencje, funkcjonowanie przedmiotowych instytucji, co zrozumiałe, w latach egzystencji pokojowej Królestwa. Okres powstania listopadowego został w nich potraktowany bardzo ogólnie,

${ }^{1}$ Nadal, jak w Księstwie Warszawskim, Rada Stanu brała udział w procedurze legislacyjnej, przygotowywać też miała dla monarchy ogólny raport o stanie państwa. Por. A. Korobowicz, W. Witkowski, Historia ustroju i prawa polskiego (1772-1918), Warszawa 2012, s. 105-108. Te zagadnienia, ponieważ nie są przedmiotem interesującej tu nas debaty władz powstania, pozostawiam na uboczu.

${ }^{2}$ W. Witkowski, Sąownictwo administracyjne w Księstwie Warszawskim i Królestwie Polskim 1807-1867, Warszawa 1984; tenże, Komisja Rządowa Sprawiedliwości w Królestwie Polskim 1815-1876, Lublin 1986. Prekursorskim tekstem o sądownictwie administracyjnym pozostaje H. Izdebskiego Sądownictwo administracyjne w Księstwie Warszawskim i w Królestwie Polskim do 1867 roku, CPH, 1974, t. XXVI, z. 2. 
choć w książce o Komisji Rządowej Sprawiedliwości znalazło się miejsce na omówienie zwłaszcza zmian personalnych w samej Komisji i w resorcie sądownictwa, będących skutkiem przemian politycznych i reakcji władz powstania związanych z negatywnymi ocenami działań wymiaru sprawiedliwości w latach 1815-1830. Nie chcąc powtarzać ustaleń dokonanych uprzednio, ograniczę się w tym miejscu do kwestii przybliżających problemy wiążące się z poruszanym tu zagadnieniem. Zacząć wypada od Komisji Rządowej Sprawiedliwości (KRS). W momencie wybuchu powstania ówczesny minister sprawiedliwości Ignacy Sobolewski nie sprawował urzędu z racji długotrwałego urlopu spowodowanego choroba, a resortem kierował Michał Woźnicki ${ }^{3}$. Struktura Komisji, ustalona jeszcze w latach 1818-1819, w okresie powstania nie uległa żadnym zmianom poza ustanowieniem stanowiska dyrektora generalnego (właściwie zastępcy) - analogicznie do pozostałych komisji rządowych. Zmieniała się natomiast jej pozycja w całokształcie coraz to nowej organizacji władz powstania. Generalnie lokowano Komisję, tak jak inne komisje rządowe, najniżej w hierarchii rozbudowanych struktur aparatu rządzącego ${ }^{4}$. Natomiast doszło w Komisji Sprawiedliwości do istotnych zmian osobowych i o nich należy wspomnieć, gdyż właśnie nowi jej członkowie będą dążyć do przywrócenia Rady Stanu. Pierwszym powstańczym ministrem sprawiedliwości został znany działacz polityczny Bonawentura Niemojowski (od 8 grudnia 1830 r.) i pełnił tę funkcję do 2 lutego $1831 \mathrm{r}$. Jeszcze przed objęciem przez niego urzędu z Komisji odwołano decyzją Rządu Tymczasowego z 3 grudnia 1830 r. sekretarza generalnego Jana Hankiewicza. Także z początkiem grudnia usunięto z Rady Administracyjnej Michała Woźnickiego, który z Komisji odszedł 30 stycznia 1831 r. ${ }^{5}$ B. Niemojowski doprowadził też, już 11 grudnia 1830 r., do zawieszenia w czynnościach dwóch pozostałych członków Komisji Antoniego Wyczechowskiego i Wincentego Ilnickiego z uzasadnieniem, że „w opinii publicznej ulegają zarzutowi, iż pod rządem przeciw któremu naród powstał przez nieprawną uległość niekonstytucyjnym rozkazom stali się narzędziem ucisku i prześladowania wielu obywateli" ${ }^{6}$. W ich miejsce w grudniu 1830 r. B. Niemojowski wprowadził do Komisji Józefata B. Ostrowskiego, prawnika, znanego z radykalizmu redaktora i działacza politycznego, na

${ }^{3}$ M. Woźnicki, nadzwyczajny radca stanu, praktycznie od 1824 r. zarządzał Komisją. Por. szerzej W. Witkowski, Komisja Rzadowa..., s. 37-38.

${ }^{4}$ Dokładnie o tym problemie i zastępczym charakterze władz resortowych piszę w pracy Komisja Rządowa..., s. 64-67.

${ }^{5}$ J. Hankiewicza powieszono w czasie wydarzeń 15/16 VIII 1831 r., tamże, s. 93-94.

${ }^{6}$ Tamże, s. 95. J. Hankiewicza i W. Ilnickiego najbardziej oskarżano o działania antykonstytucyjne i uleganie wpływom Namiestnika oraz czynników rosyjskich. 
stanowisko zastępcy sekretarza generalnego, a na wakujące stanowiska dyrektorów wydziałów (w charakterze zastępców) dotychczasowego sędziego apelacyjnego Teodora Paprockiego i głośnego prawnika, deputowanego warszawskiego Franciszka Wołowskiego. Temu ostatniemu powierzono funkcję zastępcy dyrektora generalnego, a pełnił ją od 26 grudnia 1830 r. do 3 marca 1831 r. Jednak już 11 lutego 1831 r. Wołowski na posiedzeniu Sejmu zrzekł się ministerialnego urzędu z racji niemożności łączenia go z funkcją deputowanego. Był zdania, że urzędnik nie może być deputowanym, „jeśli teraźniejsze rewolucyjne urzędy uważać chcemy jak zwyczajne" ${ }^{\prime 7}$. Do końca powstania zmian organizacyjnych ani personalnych na kierowniczych stanowiskach w Komisji nie przeprowadzono i ten okrojony skład funkcjonował w czasach Rządu Narodowego. Jak podkreślał K. Fleszyński okres ten ,,[...] z przyczyn natury zasadniczej jak i ze względu na zawieruchę wojenną nie mógł wywrzeć wpływu na dotychczasową organizację sądową" ${ }^{\prime \prime}$. Odnotować tylko trzeba, iż kolejnymi ministrami sprawiedliwości byli: Wiktor Rembieliński (od 5 lutego do 16 sierpnia 1831 r.), następnie, tu nas interesujący, Franciszek Ksawery Lewiński (od 17 sierpnia do 7/8 września 1831 r. i ostatni Jan Olrych Szaniecki (od 7/8 września do 12 września 1831 r.) 9 .

Rada Stanu Królestwa Polskiego lat konstytucyjnych nie doczekała się odrębnej monografii, jak choćby Rada Stanu w Księstwie Warszawskim ${ }^{10}$. Oddzielne opracowanie drugiej części Rady Stanu, czyli Rady Administracyjnej, zawdzięczamy Hubertowi Izdebskiemu ${ }^{11}$. W swoich badaniach dziejów sądownictwa administracyjnego zajmowałem się strukturą i składem Ogólnego Zgromadzenia Rady Stanu w latach 1815-1830 i tu chciałbym przytoczyć zasadnicze informacje przydatne do dalszego wywodu. Skład Rady Stanu Królestwa był szerszy niż Rady Stanu Księstwa Warszawskiego. Według konstytucji z 1815 r. przewodniczył jej król bądź namiestnik lub wyznaczony minister, a wchodzili do niej ministrowie stojący na czele komisji rządowych (w liczbie pięciu), radcy stanu, referendarze i osoby, „,które król zechce szczególnie do niej wezwać”, wszyscy

${ }^{7}$ Por. szerzej, tamże, s. 95-96. Rząd Narodowy zwolnił F. Wołowskiego z urzędu w Komisji, decyzją z 27 II, którą mu zakomunikowano 3 III 1831 r., Archiwum Główne Akt Dawnych [dalej: AGAD], Wtadze cywilne powstania listopadowego [dalej: WCPL], sygn. 75, s. 93-94.

${ }^{8}$ K. Fleszyński, Sądownictwo w dobie Sejmu Rewolucyjnego 1830/31, „Głos Sądownictwa" 1930, nr 12, s. 797.

${ }^{9}$ Por. ich sylwetki: W. Witkowski, Komisja Rząowa..., s. 39-42 i podane tam źródła oraz literatura.

${ }^{10}$ Por. M. Krzymkowski, Rada Stanu Księstwa Warszawskiego, Poznań 2011.

${ }^{11}$ H. Izdebski, Rada Administracyjna Królestwa Polskiego w latach 1815-1830, Warszawa 1978. 
z prawem podejmowania decyzji ${ }^{12}$. Przepisami z 17 marca 1816 r. ustalono liczbę zwyczajnych radców stanu na dziesięciu, z których dziewięciu zasiadało w komisjach rządowych (Spraw Wewnętrznych i Policji, Wojny, Przychodów i Skarbu), a dziesiąty pełnił funkcję radcy sekretarza stanu i prowadził kancelarię Rady ${ }^{13}$. Radcy stanu byli więc ściśle związani z administracją aktywną. Ponadto ustanowiono urząd radcy stanu nadzwyczajnego uprawniający na podstawie decyzji namiestnika do zasiadania i głosowania w Radzie. Z urzędu radcami stanu nadzwyczajnymi zostali Prezes Głównej Izby Obrachunkowej, członkowie Komisji Rządowej Sprawiedliwości oraz prokurator generalny stojący na czele Prokuratorii. W Radzie Stanu miało działać dziesięciu referendarzy nie wchodzących w skład komisji rządowych, a oprócz nich przewidziano możliwość powoływania referendarzy stanu nadzwyczajnych z prawem głosowania oraz wicereferendarzy. Zadaniem tych ostatnich miało być przygotowywanie spraw będących przedmiotem obrad. Mieli oni prawo uczestnictwa w posiedzeniach bez możliwości głosowania. Zwykły komplet decyzyjny wynosił co najmniej siedem osób ${ }^{14}$. Dla przygotowania spraw sądowych utworzono z początkiem 1816 r. Komisję Instrukcyjną w Radzie Stanu, składającą się z pięciu referendarzy, pod przewodnictwem jednego z radców stanu ${ }^{15}$. Dodać należy, że w latach 1816-1822 dla sprawowania sądownictwa administracyjnego funkcjonował organ o nazwie Delegacja Administracyjna. Delegacja zastępowała Radę Stanu, ale z zaznaczeniem odrębności personalnej i organizacyjnej. $W$ jej skład wchodził prezes (jeden z senatorów) i sześciu członków z dodaniem trzech asesorów „z głosem doradczym” i trzech urzędników biurowych. Kandydatów na członków i asesorów Delegacji proponować mogły do nominacji przez namiestnika komisje rządowe: Sprawiedliwości, Spraw Wewnętrznych, Skarbu - w liczbie podwójnej. Komplet orzekający stanowiły trzy osoby, a pierwszym jej prezesem został Józef Wybicki ${ }^{16}$.

2. Na początku grudnia $1830 \mathrm{r}$. decyzjami z dni od piątego do siódmego Rząd Tymczasowy polecił wszystkim organom resortowym, w tym także sądom, podjęcie czynności z jednoczesnym upoważnieniem Komisji Rządowej Sprawiedliwości do użycia stanowczych środków w celu zabezpieczenia sprawności działań sądów karnych. Jak zaraportowała KRS, nakazano prezesom trybunałów cywilnych, by "zbywających sędziów” w tychże sądach delegowano do sądów kryminalnych, a asesorów do

\footnotetext{
${ }^{12}$ W. Witkowski, Sądownictwo administracyjne..., s. 47.

${ }_{13}$ "Dziennik Praw Królestwa Polskiego" [dalej: DPKP] 1816, t. I, s. 349-352.

${ }^{14} \mathrm{~W}$. Witkowski, Sadownictwo administracyjne..., s. 48.

${ }^{15}$ Por. szerzej, tamże, s. 49-50.

16 Tamże, s. 42-47.
} 
sądów poprawczych ${ }^{17}$. Podkreślił też Rząd Tymczasowy konieczność przestrzegania zasady hierarchiczności $\mathrm{w}$ postępowaniu administracyjnym, jak i w stosunkach służbowych oraz osobowych. Z kolei Dyktator powstania zażądał od władz resortowych spisu osób, które należałoby zwolnić „dla dobra służby" i 8 grudnia KRS przedstawiła stosowną listę. Jednocześnie w grudniu t.r. w społeczeństwie Królestwa dał się zauważyć wyraźny ruch mobilizacyjny, ochotniczy, idący w stronę formowania kolejnych oddziałów wojskowych, tzw. powstań ${ }^{18}$. Jak pisał już o tym Z. Gołba, wobec mobilizacji wojskowej siłą rzeczy postępowanie w sądach ulegać musiało zakłóceniom wobec częstej niemożności stawiennictwa stron procesowych ${ }^{19}$. Dodać można, że Rząd Tymczasowy 17 grudnia 1830 r. wydał oświadczenie zezwalające $\mathrm{w}$ resorcie sprawiedliwości na udzielanie urlopów bezterminowych wszystkim pracownikom sądów udającym się do wojska ${ }^{20}$. To również wydatnie przyczyniało się do hamowania biegu postępowań sądowych. W tym stanie rzeczy KRS szybko zdecydowała się wystąpić z wnioskiem o ogłoszenie tzw. juristitium (justitium), czyli zawieszenia czynności sądowych w sprawach cywilnych ${ }^{21}$. Postanowienie w tej mierze wydał Rząd Tymczasowy „z woli Dyktatora” 15 grudnia 1830 r., a czas zawieszenia miał biec w Warszawie od 30 listopada t.r., a na pozostałym obszarze Królestwa od 5 grudnia. W ten sposób juristitium wstrzymywało bieg przedawnienia do momentu utraty mocy obowiązującej wprowadzonych przepisów. Co charakterystyczne, postanowienie, w art. 5, wyróżniało, według dawnej polskiej terminologii prawniczej preskrypcje (czyli dawność jako sposób nabycia nieruchomości poprzez niezakłócone posiadanie oraz utratę dochodzenia zobowiązań

${ }^{17}$ AGAD, WCPL, sygn. 75, s. 15-19. Na mocy postanowienia Rady Najwyższej Narodowej KRS miała składać cotygodniowe raporty o sposobie wykonywania poleceń idących „bądź wprost od Dyktatora bądź przez pośrednictwo Rady" - od 25 XII 1830 r. Pierwszy raport miał objąć czynności od 1 XII do 25 XII t.r. Ostatni raport Rządowi Narodowemu KRS złożyła za okres 16-24 VIII 1831 r. Jak z ich treści wynika, głównie zajmowano się wyjaśnianiem spraw personalnych, skarg na opieszałość postępowań sądowych, opinii o ułaskawieniach, skróceniu bądź złagodzeniu kar itp., tamże, do strony 245.

${ }^{18}$ Por. J. Skarbek, Dyktatura generata Józefa Chłopickiego, [w:] Powstanie listopadowe 1830-1831. Dzieje wewnętrzne. Militaria, Europa wobec powstania, red. W. Zajewski, Warszawa 1980 , s. 77.

${ }^{19}$ Z. Gołba, Rozwój władz Królestwa Polskiego w okresie powstania listopadowego, Wrocław-Warszawa-Kraków-Gdańsk 1971, s. 81.

${ }^{20}$ AGAD, WCPL, sygn. 75, s. 10.

${ }^{21}$ Tego rodzaju środek zastosowano już w Księstwie Warszawskim, m.in. dekretem z 15 I 1813 r. wobec zagrożeń wynikających z wkraczania armii rosyjskiej. Por. W. Sobociński, Historia ustroju prawa Księstwa Warszawskiego, Toruń 1964, s. 257. Także juristitium wprowadzono w latach 1806 i 1809, a w Królestwie Polskim w 1816 i 1855 r. Por. S. Zawadzki, Prawo cywilne obowiazujące w Królestwie Polskim, t. I, Warszawa 1860, s. 1026-1030. 
w określonym przez prawo czasie) i perempcje, tj. niepopieranie przez strony procesu sądowego w oznaczonych terminach (inaczej określana jako fatalia $)^{22}$. Natomiast w powyższym postanowieniu wyraźnie stwierdzono, że zawieszenie nie obejmuje postępowań przy naruszeniu norm prawa karnego (zarówno w kategorii przestępstw, jak i wykroczeń), $\mathrm{w}$ postępowaniach objętych kodeksem handlowym łącznie $\mathrm{z}$ procedurą upadłościowa, jak i w czynnościach wynikających z przepisów obowiązującego prawa hipotecznego (z 1818 i 1825 r. - W.W.). Także orzecznictwo sądów polubownych zostało wyłączone spod wprowadzanego juristitium. Następnie, w zakresie sądownictwa cywilnego, w postanowieniu wyliczono taksatywnie 12 kategorii spraw, które także nie podlegały zawieszeniu i miały być prowadzone łącznie z postępowaniem egzekucyjnym. Nie był to katalog zbyt obszerny, dotyczył spraw pilnych, choć różnych kategorii, związanych z wykonywaniem władztwa publicznego, ochroną własności, zabezpieczeniem wykonalności zobowiązań. Były to więc sprawy posesoryjne, jak i z tytułu naruszeń własności, dochodzenia alimentów, należności z tytułu umów dzierżawy, czynszów, komornego i wynagrodzeń służących, łącznie ze sprawami eksmisyjnymi, prowadzonych w Warszawie od 30 listopada t.r., a na obszarze Królestwa od 5 grudnia t.r, dalej, zobowiązań z umów dostawy żywności, odzieży, drewna na opał, liczonych od daty 1 października 1830 r. Następnie zaliczono tu ważną kwestię „spraw karności przeciwko urzędnikom”, jak i sprawy, które wiązały się ze stosowaniem przymusu osobistego oraz postępowań zabezpieczających przedmiot roszczenia $\mathrm{w}$ przypadku możliwości utraty go, jak choćby poprzez ucieczkę dłużnika. Postanowienie, ogłoszone publicznie, miało $\mathrm{w}$ ciągu miesiąca zostać przez Sejm zatwierdzone lub zmienione bądź uchylone.

W istocie Sejm zajął się sprawą zawieszenia biegu czynności sądowych dopiero na posiedzeniu 14 lutego $1831 \mathrm{r}^{23}$ Stosowny projekt został przygotowany w komisji do praw cywilnych i kryminalnych. Do jego autorstwa przyznał się deputowany warszawski F. Wołowski, wskazując też na znaczący udział w pracach członków komisji kasztelana Franciszka

${ }^{22}$ Tekst postanowienia znajduje się w: Diariusz Sejmu z r. 1830-1831, wydał M. Rostworowski, Kraków 1908-1912, t. II, s. 97-99 [dalej: Diariusz Sejmu]. Co do dawnego prawa polskiego por. W. Dutkiewicz, Prawa cywilne jakie w Polsce od roku 1347 do wprowadzenia kodeksu Napoleona obowiazywały, Warszawa 1869, s. 135-150. W dawnej Polsce działania wojenne również przerywały bieg przedawnienia, ale bez ogłaszania powszechnego juristitium, tylko w drodze indywidualnych czynności (tzw. manifestów). Poza ramy artykułu wykracza kwestia stosowania w praktyce sądów Królestwa Polskiego w tym czasie jeszcze reguł dawnego prawa polskiego i norm obowiązujących francuskich kodeksów cywilnych i procesowych co do przedawnienia i upadku w procesie.

${ }^{23}$ Diariusz Sejmu, t. II, s. 97-117. 
Ksawerego Lewińskiego i posła z Kalisza Stanisława Kaczkowskiego ${ }^{24}$. W czynnościach projektodawczych brał również udział minister sprawiedliwości W. Rembieliński. Jest to o tyle znamienne, że w trakcie obrad Sejmu doszło do kontrowersji właśnie między F. Wołowskim, jeszcze wówczas formalnie członkiem KRS, a W. Rembielińskim. Mianowicie F. Wołowski, uzasadniając szczegółowo projekt posłom, przedstawił nowy, znacznie rozszerzony katalog spraw w zakresie sądownictwa cywilnego wyłączonych spod juristitium. Według Wołowskiego uprzednie postanowienie Dyktatora było niedokładne i opuściło szereg przypadków „żadnej zwłoki niecierpiących", zwłaszcza że juristitium może trwać jeszcze „przez dłuższy przeciąg czasu” ${ }^{25}$. Nowa lista wyjątków obejmowała m.in. cały szereg spraw objętych księgą I Kodeksu Cywilnego Królestwa Polskiego z 1825 r., dotyczących prawa osobowego, takich jak sprostowania, zmiany $\mathrm{w}$ aktach stanu cywilnego, znoszenia przeszkód małżeńskich, kwestii upoważnień żony przez męża, ubezwłasnowolnienia, opiekuństwa i przysposobienia, a także rozwodów i unieważnień małżeństwa, chyba że "mąż zapozwany z polecenia Rządu lub dla obrony Ojczyzny w miejscu zamieszkania swego nie jest obecny" ${ }^{\prime 26}$. Następnie wyłączenia dotyczyć miały rozszerzenia stosowania przymusu osobistego (aresztu z art. 2059 i $2060 \mathrm{KN}$ ), wykonywania umów o dochody czasowe (najmu, dzierżawy), depozytu oraz kaucji, rozwiązywania pilnych problemów działów spadkowych, jak też wynikających z przepisów prawa hipotecznego z 1818 r. (tzw. wniosków illacyjnych, czyli zabezpieczających), możliwości zastosowania w sporach o własność czy posiadanie w stosunku do rzeczy administracji sądowej (sekwestru). Tak obfity katalog wyjątków od juristitium został $\mathrm{w}$ dyskusji oprotestowany zarówno przez ministra sprawiedliwości, jak i posłów oraz deputowanych. Na dwunastu mówców jedenastu wystąpiło przeciwko propozycjom Wołowskiego, w tym osoby tak znane, jak np. Ignacy Wężyk, Walenty Zwierkowski, Szczepan Świniarski, Jan Olrych Szaniecki, Konstanty Świdziński czy Kantobery Tymowski (tylko Jan Turski, poseł płocki i członek komisji był za głosem Wołowskiego). Oponenci stali na stanowisku, że w czasie wojny „o byt Ojczyzny" winno postępować się odwrotnie - wprowadzać juristitium

${ }^{24}$ O komisjach sejmowych por. S. Ziółek, Sejm Królestwa Polskiego w okresie powstania listopadowego 1830-1831, Warszawa 2007, s. 99-101, 151.

${ }^{25}$ Diariusz Sejmu, t. II, s. 101-102. Zaznaczył Wołowski, iż juristitium zarządzone w 1813 r. zamiast kilku miesięcy trwało trzy lata. W rzeczywistości funkcjonowało 2 lata, 8 miesięcy i 23 dni. Por. S. Zawadzki, Prawo cywilne obowiazujace..., s. 1026-1027.

${ }^{26}$ Dodawał Wołowski, że w sprawach o rozwód bądź unieważnienie juristitium będzie biegło już przy zaistnieniu nieobecności męża w miejscu zamieszkania „nie zaś, żeby nieobecność jego w kraju miała być dowodzoną”. Diariusz Sejmu, t. II, s. 104. 
nawet na wszystkie sprawy cywilne, by chronić obywatelskie prawa do sądu, a także nie utrudniać stosowania przepisów przez organy wymiaru sprawiedliwości ${ }^{27}$. W efekcie F. Wołowski przyjął argumenty opozycjonistów i zdecydowano odesłać projekt do dalszych prac w połączonych komisjach sejmowych z udziałem ministra oraz członków KRS. Za podstawę działań miało nadal służyć postanowienie Dyktatora z 15 grudnia 1830 r. i, jak słusznie zauważył K. Świdziński, „główna zasada projektu jest nader ważna, tj. że jakkolwiek winniśmy zawiesić spory o rzecz, nie mamy prawa wystawiać stron na zgubę przedmiotu"28. Sejm powstania nie podjął jednak już dalszych prac $\mathrm{w}$ tym przedmiocie i w konsekwencji nadal obowiązywały przepisy z grudnia $1830 \mathrm{r}^{29}$

Jak więc widać, juristitium w sądownictwie powszechnym nie miało i nie mogło mieć, z wielu względów, całościowego charakteru i dopuszczało wyjątki. Problem ten nie wystąpił początkowo w zakresie sądownictwa administracyjnego. Dyktator powstania postanowieniem z 28 grudnia 1830 r. zawiesił zupełnie działalność sądów administracyjnych, tj. komisji wojewódzkich w I instancji i Rady Stanu w II, z mocą obowiązującą od 30 listopada t.r. ${ }^{30}$ Dodać należy, iż od momentu wybuchu powstania i powoływania nowych, kolejnych jego władz Rada Stanu praktycznie nie zbierała się i tym samym zaprzestała funkcjonowania. Sejm na posiedzeniu 29 stycznia 1831 r. zawiesił m.in. przepisy konstytucji Królestwa zawarte w rozdziale III tytułu trzeciego, a więc dotyczące Rady Stanu i tym samym organ ten odtąd formalnie nie był zdolny do działań ${ }^{31}$.

3. Jednak w Sejmie powstańczym do kwestii funkcjonowania Rady Stanu powrócono, wiążąc ją m.in. z zagadnieniem wyżej omówionego zawieszenia biegu czynności sądowych. Stało się to już u schyłku powstania na posiedzeniach z 27 i 30 sierpnia 1831 r. Wówczas, z wniosku Rządu

${ }^{27}$ M.in. poseł lubelski Józef Rozenwerth mówił: „korzystniej będzie dla kraju, by pieniądze na honorarium i wyjęcie wyroków wydać się miane, były złożone na ołtarzu Ojczyzny, do założenia tym silniejszej opozycji przeciw Dybiczowi Zabałkańskiemu, który usiłuje wywłaszczyć nas wszystkich z praw i swobód wolności, z praw człowiekowi przyrodzonych. Ustawę z d. 15 grudnia r.z. jeżeli nie ścieśnić, to nigdy rozszerzyć się nie godzi...", tamże, s. 111 .

${ }^{28}$ Tamże, s. 113.

${ }^{29}$ Juristitium zaprowadzone przez władze powstania obowiązywało do 25 XII 1831 r., kiedy zostało zniesione decyzją Rządu Tymczasowego Królestwa Polskiego. S. Zawadzki, Prawo cywilne..., t. I, s. 1027-1028.

${ }^{30}$ W. Witkowski, Sądownictwo administracyjne..., s. 25. Por. też S. Zawadzki, Prawo cywilne..., t. I, s. 1028. Po upadku powstania niektóre sądy administracyjne I instancji same podjęły działalność $\mathrm{w}$ latach 1832-1833, ale formalnie juristitium ustało z datą 18/30 III 1835 r. Rada Stanu rozpoznawanie sporów administracyjnych rozpoczęła 17 IX 1836 r. W. Witkowski, Sąownictwo administracyjne..., s. 30.

${ }^{31}$ Diariusz Sejmu, t. I, s. 365. 
Narodowego (i zaopiniowaniu przez komisje sejmowe), debatowano nad projektem uchwały przywracającej niektóre kompetencje Rady Stanu, a ich czasowe rozstrzyganie przekazywano odrębnej Delegacji („,do czasu uorganizowania na nowo Rady Stanu"). Kompetencje te obejmowały trzy kategorie spraw: 1) decydowania o oddawaniu pod sąd urzędników administracyjnych mianowanych przez władze rządowe „za przestępstwa w urzędzie wyjąwszy tych co są Sądowi Sejmowemu ulegli"; 2) orzekania w sporach kompetencyjnych (jurysdykcyjnych) w postępowaniach wyłączonych od juristitium; 3) w sprawach o przyznanie ulg w podatkach (w tzw. postępowaniu allewiacyjnym $)^{32}$. Wynikały one z uprawnień Rady Stanu na mocy art. 73 konstytucji Królestwa Polskiego oraz przepisów z 20 lutego 1816 r. przywracających sądownictwo administracyjne z czasów Księstwa Warszawskiego ${ }^{33}$. W ten sposób czyniono wyłom w juristitium $\mathrm{w}$ zakresie sądownictwa administracyjnego (sprawy allewiacyjne), a i w wyjątkach w dziedzinie spraw cywilnych wprowadzono (właściwie przywracano - W.W.) tryb postępowania angażujący w sporze władze sądowe oraz administracyjne w celu ustalenia uprawnień co do orzekania. $\mathrm{W}$ tej materii, przy nader skomplikowanym stanie prawnym, zwłaszcza w relacjach obywateli z administracją skarbowa, orzecznictwo Rady Stanu mogłoby doprowadzać do wkraczania w przepisy o juristitium tak co do sądownictwa powszechnego, jak i administracyjnego ${ }^{34}$. Twórcy projektu, wychodzącego z Komisji Rządowej Sprawiedliwości, uzasadniali go krótko: „przedmioty wyżej wspomniane są tego rodzaju, że rozstrzygnięcie ich zwłoce ulegać nie powinno" ${ }^{35}$. Współczesny autor S. Ziółek, i tak jako jeden $\mathrm{z}$ nielicznych wspominający o tym projekcie, nazwał go lapidarnie "nieistotnym z punktu widzenia toczących się wypadków”, ale dodał, iż „wprowadzenie go pod obrady i przyjęcie było kolejnym dowodem, że Sejm konsekwentnie odbudowywał stosunki wewnętrzne Królestwa Polskiego i dostosowywał je do warunków funkcjonowania niepodległe-

${ }^{32}$ Projekt (cztery artykuły) przedstawiał deputowany W. Zwierkowski, Diariusz Sej$m u \ldots$, t. VI, s. 466-467.

${ }^{33} \mathrm{O}$ odpowiedzialności urzędników cywilnych por. G. Smyk, Korpus urzędników cywilnych w guberniach Królestwa Polskiego w latach 1867-1915, Lublin 2004, s. 110. O pozostałych uprawnieniach Rady Stanu patrz szerzej W. Witkowski, Sadownictwo administracyjne..., s. 17 i n.

${ }^{34}$ Por. W. Witkowski, Sadownictwo administracyjne..., s. 80-87. Szczególnie w przedmiotach dotyczących umów dzierżawnych, czynszów i opłat, kontraktów dostawy, w kontekście obowiązywania przepisów z 11 X 1816 r. O urządzeniu Prokuratorii Generalnej, przekazujących do drogi administracyjnej cały szereg spraw tego rodzaju, obok odrębnych unormowań dotyczących sądownictwa administracyjnego. Szerzej, tamże, s. 61-64.

${ }^{35}$ Diariusz Sejmu, t. VI, s. 466. 
go państwa" ${ }^{36}$. Z poglądem S. Ziółka wypada się zgodzić, ale zarazem podkreślić, że podjęcie tej materii przez członków Sejmu dawało dobitne i aktualne świadectwo troski o poszkodowanych działaniami wojennymi mieszkańców Królestwa (ulgi podatkowe) ${ }^{37}$. Częściowe odblokowanie sądownictwa kompetencyjnego, tak ważne z punktu widzenia gwarancji praworządności, dowodziło też podjęcia słusznej reakcji legislacyjnej spowodowanej praktycznymi trudnościami w stosowaniu prawa przez obywateli oraz organy administracyjne i sądowe. Otóż cały szereg skarg, zażaleń czy też próśb mieszkańców Królestwa związanych z działalnością administracji bądź też sądów, był składany w nowych warunkach struktur władz powstańczych bezpośrednio do Rządu Tymczasowego, a następnie Rady Najwyższej Narodowej i Rządu Narodowego ${ }^{38}$. Organy te zazwyczaj zwracały się o opinie do komisji rządowych, a najczęściej do KRS, w celu ustalenia drogi postępowania i możliwości wydania decyzji. Katalog spraw był nader różnorodny, oprócz oczywistych kwestii natury administracyjnej dotyczył też ingerencji w wymiar sprawiedliwości. Wnioskodawcy żądali m.in. rozpoczęcia bądź wznowienia śledztw sądowych, jak i ich przyśpieszenia, możliwości rozstrzygnięcia sporów z kontraktów zawieranych z władzami publicznymi (dostaw, budowy budynków itp.). Były nawet sprawy z zakresu stosunków rodzinnych, np. dotyczące wielożeństwa bądź odzyskania przez ojca od matki swoich dzieci „za pomocą wojskową”. KRS starała się wskazywać na granicę między drogą administracyjną a sądową $\mathrm{w}$ warunkach istniejącego juristitium. W kontekście jednej ze spraw wprost pisała, iż kompetencje rozstrzygnięcia należą wyłącznie do sądu, gdyż „Komisji Rządowej Sprawiedliwości nie służy atrybucja rozstrzygnienia kwestii spornych prywatnych stosunków stron lub trudności egzekucji dotyczących się" ${ }^{\prime \prime 39}$. Niemniej potrzeba powołania organu rozstrzygającego spory kompetencyjne, u których początku leżały żądania pokrzywdzonej strony, stawała się dominująca. Zwłaszcza, iż liczba spraw była niemała, a centralizm władz, przy pewnej dezorientacji obywateli w warunkach wojennych, powodował wybór najprostszej drogi, tj. żądania rozpoznania w trybie administracyjnym, nie zawsze prawnie właściwym. Przy jednoczesnych,

${ }^{36}$ S. Ziółek, Sejm Królestwa..., s. 264. Z tym że autor niezbyt dokładnie informuje o treściach projektu, ograniczając się do kwestii decydowania o oddaniu pod sąd urzędników administracyjnych.

37 Skala zniszczeń pozbawiających właścicieli dochodów była znaczna i dopiero w czasach II Rady Stanu Królestwa Polskiego uporano się z problemem ulg z powodu klęsk wojny 1831 r. Por. szerzej W. Witkowski, Sąownictwo administracyjne..., s. 156-162.

${ }^{38}$ Por. AGAD, WCPL, sygn. 75, s. 15 do końca, tj. s. 245; także AGAD, WCPL, sygn. 140 (Miscellanea $z$ sekcji sprawiedliwości), passim.

${ }^{39}$ AGAD, WCPL, sygn. 140, s. 254. 
zrozumiałych wówczas, trudnościach $\mathrm{w}$ funkcjonowaniu sądownictwa tylko rozpoznanie przez organ zewnętrzny, jakim była - mimo pewnych ułomności - Rada Stanu, mogło przynieść drogą orzecznictwa rozstrzyganie konfliktów oraz jasne i trwałe zasady postępowania ${ }^{40}$. Trzeci obszar działań wznawianej Rady Stanu, tj. udzielania zgody na postawienie urzędnika przed sądem, także dobrze świadczył o znajomości funkcjonowania władz powstańczych w zakresie polityki personalnej, jak i prawnej strony grupy zawodowej, jaką byli mianowani urzędnicy publiczni. Urzędnicy ci, od czasów Księstwa Warszawskiego, mieli swego rodzaju immunitet, na wzór immunitetu parlamentarnego czy sędziowskiego. Jak przekonująco uzasadnił to M. Krzymkowski, jego istotą było właśnie wydawanie wyżej wspomnianej zgody przez Radę Stanu ${ }^{41}$. Z pewnością autorzy projektu, wywodzący się ze sfer rządowo-urzędniczych, byli zainteresowani przywróceniem tego przywileju, także w czasie działań powstańczych. Urzędnicy, szczególnie wyżsi, pozbawieni tego rodzaju ochrony od samego początku powstania, mieli poczucie destabilizacji urzędów, zwłaszcza przy radykalnej polityce personalnej władz rządowych, często zależnej od uwarunkowań politycznych, walki stronnictw czy też antagonizmów osobistych bądź nacisków opinii publicznej. Choć, jak zauważał J. Skowronek, w powstaniu administracja resortowa dzięki „doświadczeniu praktycznemu jej kadr funkcjonowała sprawnie”, to jak widać potrzeba immunitetu urzędniczego dawała się wyraźnie odczuć i temu celowi miała służyć inicjatywa Rządu Narodowego ${ }^{42}$.

Delegacja, której czasowo powierzono rozstrzyganie powyższych spraw, miała składać się z siedmiu członków nominowanych przez prezesa Rządu Narodowego spośród „wyższych urzędników sądowych i administracyjnych". Odrębnie prezes Rządu Narodowego powoływał tzw. Komisję Instrukcyjną złożoną z pięciu osób (radcy stanu i czterech referendarzy), której zadaniem miało być prowadzenie postępowania przygotowawczego. Postępowanie w obydwu organach winno toczyć się według przepisów obowiązujących przed wybuchem powstania. W ten sposób twórcy projektu nawiązywali do uprzedniej konstrukcji Delegacji Administracyjnej, która zastępowała Radę Stanu w latach 1816-1822, jak

${ }^{40}$ O genezie, pojęciu sporów kompetencyjnych, jak też orzecznictwie Rady Stanu Księstwa Warszawskiego i Królestwa Polskiego pisze celnie R. Jastrzębski, Trybunał Kompetencyjny, Warszawa 2014, s. 15-46.

${ }^{41}$ M. Krzymkowski, Status prawny urzędników Księstwa Warszazwskiego, Poznań 2004, s. 146.

${ }^{42}$ J. Skowronek, Rząd Narodowy, [w:] Powstanie listopadowe 1830-1831. Dzieje wewnętrzne..., s. 121. 
i działającej przy niej Komisji Instrukcyjnej ${ }^{43}$. Skład nowej Delegacji miał, podobnie jak we wcześniejszej, odbijać uprawnienia w zakresie sądownictwa prawa publicznego i orzekania w trybie administracyjnym ${ }^{44}$.

Dyskusję nad projektem na posiedzeniu Sejmu w dniu 27 sierpnia 1831 r. rozpoczął minister sprawiedliwości Fr. Ks. Lewiński. Nie ograniczył się do ogólnego poparcia projektu uchwały, ale w obszerniejszym głosie przedstawił swoją ocenę działań resortu sprawiedliwości w okresie przedpowstańczym. Poddał ostrej krytyce poczynania ministrów sprawiedliwości i podległego im aparatu, powolnych wobec władz rosyjskich, naruszających zasady niepodległości sądownictwa oraz niezawisłości sędziów, działających wręcz antykonstytucyjnie przeciwko obywatelom i własności prywatnej. Powoływał się na przykłady naruszeń zasady nietykalności osobistej (art. 18 i 19 konstytucji), prawa do sądu (art. 21 konstytucji), znaną sprawę procesu Towarzystwa Patriotycznego, wprowadzenia cenzury, dokonywania administracyjnych wywłaszczeń wbrew art. 26 i 27 Konstytucji. Następnie negatywnie ocenił brak wprowadzenia organizacji sądownictwa przewidzianego konstytucją oraz ciągłe utrzymywanie norm karnej procedury pruskiej i austriackiej. Uznał także, że Kodeks Karzący z 1818 r. jest „napełniony przepisami niestosownymi dla kraju naszego", a szczególną wadę sądownictwa widział w odejściu w Królestwie Polskim od instytucji kasacji. Tylko sąd kasacyjny, mówił, ,jest najwyższym dozorcą przestrzegającym obrony prawa [...] od czego bezpieczeństwo własności i osób, a zatem pomyślność kraju zawisła"45. Po wystąpieniu ministra sprawiedliwości do projektu odniósł się deputowany F. Wołowski. Poparł go generalnie, ale zgłosił uwagi dotyczące zbyt małego składu orzekającego Delegacji i odrębnego usytuowania Komisji Instrukcyjnej - w stosunku do rozwiązań funkcjonujących przed rokiem 1830. Następni mówcy, m.in. senatorowie Andrzej Rufin Walchnowski, Antoni Bieńkowski, poseł Ksawery Godebski, podnieśli formalną usterkę $\mathrm{w}$ toku procedowania, jaką był brak przedstawicieli Senatu w czasie prac nad projektem $w$ komisjach sejmowych ${ }^{46}$. W efekcie zgodzono się na zwrot projektu do komisji Sejmu w celu opracowania wniosków zgło-

${ }^{43}$ Por. szerzej W. Witkowski, Sadownictwo administracyjne..., s. 42-47, 49-50.

${ }^{44}$ Wskazano tu, choć dość ogólnie, na przedstawicieli wyłącznie sądownictwa i administracji, a do Delegacji z 1816 r. kandydatów miały przedstawiać trzy komisje rządowe: Sprawiedliwości, Spraw Wewnętrznych i Skarbu, tamże, s. 43.

${ }^{45}$ Diariusz Sejmu, t. VI, s. 467-469.

${ }^{46}$ Senatorowie twierdzili, że nie zostali prawidłowo powiadomieni o posiedzeniu komisji. Brał w niej udział tylko jeden senator Michał Aleksander Potocki, który o obradach dowiedział się przez przypadek, na ulicy, od jednego z członków Izby Poselskiej, tamże, s. $469-477$. 
szonych przez F. Wołowskiego, idących w kierunku zmian w organizacji i składzie powoływanych organów.

Z komisji przepracowany projekt wrócił do Sejmu 30 sierpnia $1831 \mathrm{r}^{47}$ W porównaniu z wersją poprzednią rozszerzono skład Delegacji do dziesięciu osób, rekrutujących się z radców stanu, referendarzy i sędziów Sądu Najwyższej Instancji. Delegacja orzekać miała większością głosów w kompletach co najmniej siedmioosobowych, pod przewodnictwem najstarszego z sędziów według porządku nominacji. Z kolei Komisję Instrukcyjną usytuowano jako wewnętrzny organ Delegacji. Jej członkowie w zmniejszonej liczbie trzech mieli prawo zasiadać w składzie orzekającym z "głosem stanowczym". Ograniczenie powodujące wyłączenie $\mathrm{z}$ prac Delegacji stanowił udział w postępowaniu przed niższą instancją. Pozostałe przepisy odnoszące się do kompetencji i stosowania norm proceduralnych pozostały bez zmian. Dyskusja nad projektem była dość żywa, wzięło w niej udział kilkunastu mówców, niektórzy zabierali głos parokrotnie. Bezpośrednio poparli go minister sprawiedliwości Fr. Ks. Lewiński i F. Wołowski, a do nich dołączyli m.in. deputowany sandomierski Jan Posturzyński, poseł kaliski Teofil Morawski, poseł płocki Wincenty Chełmicki i senator wojewoda Antoni Gliszczyński. Pewne kontrowersje wywołał wniosek deputowanego augustowskiego Jakuba Klimontowicza proponującego, by w składzie Delegacji byli wyłącznie „teraźniejsi, czynni radcy stanu i referendarze", a także postulat W. Chełmickiego rozszerzenia składu o sędziów apelacyjnych. W wyniku głosów przeciwnych, a szczególnie broniącego projektu F. Wołowskiego, obydwaj wycofali się ze swoich propozycji ${ }^{48}$. Interesującą wypowiedź przedstawił poseł mazowiecki Szczepan Swiniarski twierdząc, iż „...szczęściem od powstania naszego nie liczymy urzędników administracyjnych, którzyby zasługiwali na oddanie ich pod sąd. Są tacy, którzy w sumieniu się osądzili, podali do dymisji, oddalili z kraju i przez to rozumieją, że unikną wszelkiej odpowiedzialności..." ${ }^{49} \mathrm{Z}$ drugiej strony podawał przykłady nepotyzmu w obsadzaniu urzędów na terenie obwodu gostyńskiego i dodawał, że liczy na prawidłowe wymierzanie sprawiedliwości przez Delegację. Pogląd Świniarskiego uzupełniał J. Posturzyński zauważając, że przedmiotowy projekt, ze względu na wagę spraw jest i tak już za późno decy-

${ }^{47}$ Tamże, s. 479-481.

${ }^{48}$ J. Klimontowiczowi odpowiadano, iż nie można Rządowi Narodowemu blokować prawa swobodnej nominacji radców stanu i referendarzy. J. Klimontowicz z kolei wyrażał obawę, że władze rządowe mogłyby „z dawnych radców stanu wybierać członków Delegacji a wtenczas okazałoby się czczem prawo sejmowe, które rozwiązało dawną Radę Stanu", tamże, s. 491-495.

${ }^{49}$ Tamże, s. 483. 
dowany, a umożliwi władzom rządowym aktywne postępowanie także w sprawach "tych Polaków, którzy przyjęli urzędy na stronę Moskali" 50 .

Znaczącą część dyskusji zajęła sprawa sądownictwa administracyjnego, częściowo tylko wiążąca się z omawianym projektem, ale żywo obchodząca sfery urzędnicze i opinię publiczną Królestwa. Jak już pisałem w 1984 r., odbywająca się w czasach Księstwa Warszawskiego krytyka tego sądownictwa przybrała na sile w Królestwie. Ścierały się zasadniczo dwie koncepcje: jedna za oddaniem sporów administracyjnych sądom zwyczajnym, druga za utrzymaniem sądownictwa administracyjnego. Oponenci sądów administracyjnych znajdowali się w gronie członków Rady Administracyjnej i Komisji Rządowej Sprawiedliwości, natomiast konsekwentną zwolenniczką sądów administracyjnych była Komisja Rządowa Przychodów i Skarbu. Atakowano zasady sądownictwa administracyjnego, widząc $w$ nich szczególne uprzywilejowanie administracji, nie godzące się z liberalizmem życia gospodarczego, wytykano jego wady, zwłaszcza brak prawa materialnego i procedury oraz związaną z tym przewlekłość postępowań. Na każdym Sejmie Królestwa wnoszono petycje żądające likwidacji sądownictwa administracyjnego jako niekonstytucyjnego ${ }^{51}$. Właśnie w sejmie powstańczym, wolnym od zewnętrznych ingerencji i nacisków, przy okazji dysputy o wznowieniu Rady Stanu, żądania zniesienia sądów administracyjnych ujawniły się $\mathrm{z}$ całą wyrazistością. Debatę rozpoczął K. Tymowski częściowo znanym i cytowanym już twierdzeniem, które tu warto dokładnie przytoczyć: „Działania Sejmu szczególniej do tego zmierzać powinny, iżby wszelkie instytucje antykonstytucyjne usuwać i wszystko niszczyć, co tylko nosi na sobie cechę systematu despotycznego. Projekt niniejszy ze względu tego uważam za antykonstytucyjny, za utwierdzający sądy administracyjne, ten potwór, z którego tyle urodziło się bezprawiów, na którego zagładę tak długo i tak nadaremnie naród polski nalegał"52. Dalej K. Tymowski obszernie uzasadniał konieczność przekazania w całości uprawnień sądów administracyjnych sądownictwu zwyczajnemu, a w odniesieniu do przedmiotowego projektu był zdecydowanym przeciwnikiem immunitetu urzędniczego jako naruszającego zasadę równości wobec prawa i dającego pole do licznych nadużyćs3. Także postępowanie w zakresie

50 Tamże, s. 484 .

${ }^{51}$ W. Witkowski, Sadownictwo administracyjne..., s. 25-26.

${ }^{52}$ Diariusz Sejmu, t. VI, s. 485. Fragment cytował H. Izdebski, Rada Administracyjna..., s. 124.

${ }^{53} \mathrm{Z}$ doświadczenia wiemy, dodawał, że w grupie urzędniczej wzajemne powiązania i interesy prowadzą zazwyczaj do tuszowania nadużyć władzy i innych występków, Diariusz Sejmu, t. VI, s. 486-487. 
allewiacji podatkowych charakteryzuje się, jego zdaniem, brakiem obiektywizmu i orzekaniem przez organy administracyjne w "swoich sprawach" ze szkodą dla obywateli, jak również przewlekłością orzekania. Likwidacja sądów administracyjnych przyniesie też zanik sporów kompetencyjnych. W związku z tym generalnie opowiedział się przeciwko projektowi wznawiania instytucji Rady Stanu i proponował przejęcie jej uprawnień sądowych przez sądownictwo zwyczajne. Stanowisko K. Tymowskiego zyskało poparcie w głosach Stanisława Kaczkowskiego, posła z kaliskiego i deputowanego sandomierskiego Jana Posturzyńskiego. Obydwaj uważali przywrócenie Rady Stanu, a więc sądownictwa administracyjnego, za sprzeczne z konstytucją a Posturzyński wezwał Rząd Narodowy do natychmiastowej likwidacji tegoż sądownictwa. Twierdził, nie bez racji, że z faktu milczenia konstytucji Królestwa w przedmiocie sądownictwa administracyjnego i utrzymywania go decyzjami władz administracyjnych „ubocznie jako pozostałość Księstwa Warszawskiego" aktualnie "to nadużycie Rząd sam obecny usunąć może i powinien bez dołożenia się Sejmu" ${ }^{54}$. Tym radykalnym głosom przeciwstawiła się jednak kolejna grupa dyskutantów, z ministrem sprawiedliwości Fr. Ks. Lewińskim na czele. Uważali oni, że w przyszłości, w warunkach niepodległego państwa, należy podjąć debatę nad celowością utrzymywania sądownictwa administracyjnego, a obecny projekt dotyczy tylko jego niektórych elementów, wymagających bezzwłocznego załatwienia i tym samym nie jest sprzeczny z konstytucją. F. Ks. Lewiński optował za wznowieniem wskazanych czynności Rady Stanu, która jako odrębny organ zapewni bezstronność postępowania i da gwarancje równowagi ustrojowej między władzą administracyjną a sądową. Poparł go Fr. Wołowski, wskazując na czas debaty, na to, że aktualnie "trzeba naprzód o tem myśleć, żeby być, a potem jak najlepiej się urządzić" ${ }^{55}$. W tym samym duchu wypowiedzieli się reprezentujący województwo kaliskie poseł Teofil Morawski i deputowany Antoni Rembowski, jak również senator wojewoda Antoni Gliszczyński. Z poparciem projektu wystąpił także poseł sandomierski Konstanty Świdziński, ale opowiedział się w ogóle za utrzymaniem sądownictwa administracyjnego. Polemicznie, wobec K. Tymowskiego, wskazywał na zalety tego sądownictwa w systemie trójpodziału władz i niebezpieczeństwa płynące z oddania sporów administracyjnych sądownictwu zwyczajnemu. Powoływał się w tej materii na dobre wzory zachodnioeuropejskie i zdecydowanie oświadczał: „,jeżeli za rządu rosyjskiego dla nadużyć, jakich się dopuszczały sądy administracyjne, Sejmy

\footnotetext{
${ }^{54}$ Tamże, s. 490.

${ }^{55}$ Tamże, s. 489.
} 
przeciwko nim powstawały, był to jeden ze środków opozycji dla obalenia rządu zeszłego; ale w zwyczajnych okolicznościach o potrzebie takich sądów jak najmocniej przekonany jestem" ${ }^{26}$.

Po zamknięciu dyskusji, w wyniku głosowania projekt został przyjęty zdecydowaną większością - 91 członków Sejmu głosowało za, a 20 było przeciwko. Podjęta w ten sposób uchwała, z powodu rychłego upadku powstania, nie weszła jednak w życie. Popowstaniowej Radzie Stanu sprawy z zakresu sądownictwa administracyjnego polecono rozpoznawać dopiero w 1836 r., po zniesieniu rok wcześniej obowiązującego cały czas w tej materii juristitium ${ }^{57}$.

Uchwała o wznowieniu działań Rady Stanu, jak i kontekst dyskusji poświęconej kwestiom juristitium, funkcjonowania sądownictwa administracyjnego czy odpowiedzialności urzędniczej wystawiają dobre świadectwo władzom powstańczym. Jest rzeczą oczywistą że w trakcie działań wojennych sprawy wymiaru sprawiedliwości dla ludności cywilnej schodziły na plan dalszy. Niemniej jednak nie mogły zupełnie pozostawać bez opieki państwa czy też "tkwić w bezczynności". Na tym polu poczynania Rządu Narodowego i Sejmu wyrażały wyraźną troskę o prawne bezpieczeństwo mieszkańców Królestwa tak w zawieszeniu biegu spraw sądowych, jak i dochodzeniu ulg podatkowych z tytułu zniszczeń wojennych. Wydaje się, że debatując w końcu sierpnia 1831 r. członkowie Sejmu zdawali sobie sprawę z trudności, jeśli wręcz nie niemożliwości zrealizowania podjętej uchwały, niemniej próbowali zabezpieczyć interesy ludności cywilnej. Nikt z nich nie znał skali represji, jaką zastosują zwycięscy Rosjanie, ale mieli prawo przypuszczać, że instytucje prawno-ustrojowe, będące przedmiotem tychże konkretnych decyzji, zostaną utrzymane. Funkcjonowały one ciągle od czasów Księstwa Warszawskiego, mieściły się w odmiennym od Rosji reżimie państwowym Królestwa Polskiego i - jak wynika z powyższych wywodów - znajdowały swe miejsce w poczynaniach władz powstańczych. Jak okazało się po upadku powstania listopadowego, było to postępowanie przenikliwe i choć niepodległość została utracona, to zarówno Rada Stanu z kompetencjami w zakresie sądownictwa prawa publicznego, jak i odrębności organów administracyjnych, a zwłaszcza sądowych (na czele z Komisją Rządową Sprawiedliwości) pozostały nadal w ustroju Królestwa Polskiego.

${ }^{56}$ Tamże, s. 494. O zagranicznych rozwiązaniach dotyczących ówczesnego sądownictwa administracyjnego por. H. Izdebski, Rada Administracyjna..., s. 138-143.

${ }^{57}$ Por. szerzej o dyskusji nad wznowieniem działalności sądów administracyjnych po powstaniu listopadowym, W. Witkowski, Sadownictwo administracyjne..., s. 27-30. 


\section{Bibliografia}

\section{Źródła}

Archiwum Główne Akt Dawnych [dalej: AGAD], Władze cywilne powstania listopadowego [dalej: WCPL], sygn. 75.

AGAD, WCPL, sygn. 140 (Miscellanea z sekcji sprawiedliwości).

Diariusz Sejmu z r. 1830-1831, wydał M. Rostworowski, Kraków 1908-1912, t. I, t. II., t. VI.

„Dziennik Praw Królestwa Polskiego" 1816, t. I.

\section{Opracowania}

Dutkiewicz W., Prawa cywilne jakie w Polsce od roku 1347 do wprowadzenia kodeksu Napoleona obowiazywaty, Warszawa 1869.

Fleszyński K., Sadownictwo w dobie Sejmu Rewolucyjnego 1830/31, „Głos Sądownictwa" 1930, nr 12.

Gołba Z., Rozwój władz Królestwa Polskiego w okresie powstania listopadowego, Wrocław-Warszawa-Kraków-Gdańsk 1971.

Izdebski H., Rada Administracyjna Królestwa Polskiego w latach 1815-1830, Warszawa 1978.

Izdebski H., Sądownictwo administracyjne w Księstwie Warszawskim $i$ w Królestwie Polskim do 1867 roku, CPH, 1974, t. XXVI, z. 2.

Jastrzębski R., Trybunat Kompetencyjny, Warszawa 2014.

Korobowicz A., Witkowski W., Historia ustroju i prawa polskiego (1772-1918), Warszawa 2012.

Krzymkowski M., Rada Stanu Księstwa Warszawskiego, Poznań 2011.

Krzymkowski M., Status prawny urzędników Księstwa Warszawskiego, Poznań 2004.

Skarbek J., Dyktatura generała Józefa Chłopickiego, [w:] Powstanie listopadowe 18301831. Dzieje wewnętrzne. Militaria, Europa wobec powstania, red. W. Zajewski, Warszawa 1980.

Skowronek J., Rzad Narodowy, [w:] Powstanie listopadowe 1830-1831. Dzieje wewnętrzne. Militaria, Europa wobec powstania, red. W. Zajewski, Warszawa 1980.

Smyk G., Korpus urzędników cywilnych w guberniach Królestwa Polskiego w latach 1867-1915, Lublin 2004.

Sobociński W., Historia ustroju prawa Księstwa Warszawskiego, Toruń 1964.

Witkowski W., Komisja Rządowa Sprawiedliwości w Królestwie Polskim 1815-1876, Lublin 1986.

Witkowski W., Sadownictwo administracyjne w Księstwie Warszawskim i Królestwie Polskim 1807-1867, Warszawa 1984.

Zawadzki S., Prawo cywilne obowiazujące w Królestwie Polskim, t. I, Warszawa 1860.

Ziółek S., Sejm Królestwa Polskiego w okresie powstania listopadowego 1830-1831, Warszawa 2007. 